\title{
スクッテルダイト化合物の高垥成と物性
}

\section{High-Pressure Synthesis and Physical Properties of Skutterudite Compounds}

\author{
関根 ちひろ \\ 城谷 一民 \\ Chihiro SEKINE \\ Ichimin SHIROTANI
}

\begin{abstract}
Skutterudite compounds have recently attracted much attention from the viewpoint of both their potential as improved thermoelectric materials and their variety of electrical and magnetic properties, including exotic superconductivity, quadrupole ordering and anomalous metal-insulator transition. High-pressure synthesis is a powerful technique to prepare skutterudite compounds. In this article, the high-pressure synthesis of skutterudite compounds and their physical properties are reviewed.
\end{abstract}

[high-pressure synthesis, thermoelectric material, superconductivity, metal-insulator transition]

\section{1.はじめに}

工業用材料あるいは基礎科学的な研究対象として、 これまで多くの物質が合成されてきた。それに伴い 試料作成技術も飛躍的に進歩し、これまで合成が困 難であった物質も合成できるようになってきた。高 圧合成法は、ダイヤモンド、黒リンなど常圧では合 成が困難な物質を合成できる強力な試料作成手段の 一つである。高温超伝導体の分野などでも広く材料 開発に利用されており、常圧下では得られない新規 な結晶構造を有する高性能材料を合成しうる方法と して注目されている。スクッテルダイト化合物は熱 電変換材料への応用が期待されている物質であるが、 さらに近年、異方的超伝導、四極子転移、重い電子 系的振舞、非フェルミ液体的振舞、金属一絶縁体転移 などの強相関電子系物質に特有の異常物性を示すこ とが明らかとなり、固体物理学研究者の注目を集め ている物質でもある。

スクッテルダイト化合物は $\mathrm{CoAs}_{3}$ など天然に産 するコバルト鉱石の中に発見された化合物である。 スクッテルダイトという名前はこの鉱石を産する ノルウェーの地名に由来している。スクッテルダイ 卜化合物には $\mathrm{CoAs}_{3}$ 等の二元系の非充填スクッテ ルダイト化合物の他に三元系の充填スクッテルダ
イト化合物が存在することが知られている $[1]$ 。一般 形はそれぞれ、 $\mathrm{TX}_{3}, \mathrm{RT}_{4} \mathrm{X}_{12}(\mathrm{R}=$ 希土類金属、 $\mathrm{T}=\mathrm{Co}$, $\mathrm{Fe}, \mathrm{Ru}, \mathrm{Os}$ 等の遷移金属、X= P, As, Sbのプニクトゲ ン元素) と表される。 $\mathrm{R}, \mathrm{T}, \mathrm{X}$ の各元素の組み合わせ によって、100 種類以上のスクッテルダイト化合物 が考えられ、実際、多くの化合物の合成が報告され ている。しかし、試料作成が非常に困難なため、一 部の化合物を除いて詳しい物性測定はほとんど行 われていない。

スクッテルダイト化合物は従来、フラックス法に よる単結晶育成や常圧合成後にホットプレスによっ て焼結体とする方法で作成されてきた。しかし、こ れらの方法では、大型単結晶や純良な単一相を得る ことは極めて困難であった。そこで、我々は数 $\mathrm{GPa}$ の固体圧を利用する高温高圧合成法を用いてスクッ テルダイト化合物の合成を試みた。その結果、新物 質を含む多くのスクッテルダイト化合物の単一相の 合成に成功した。本稿では我々が行ってきた高圧下 でのスクッテルダイト化合物の試料合成方法とその 特異な物性について紹介する。

\section{2. 結晶構造}

Fig.1 (a), (b) に充填スクッテルダイト化合物の結 


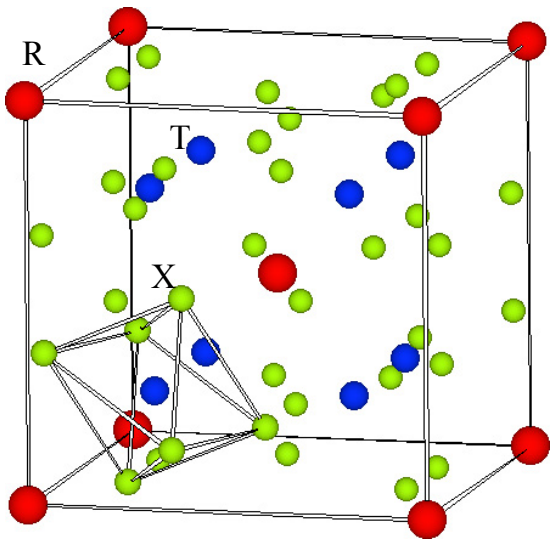

(a)

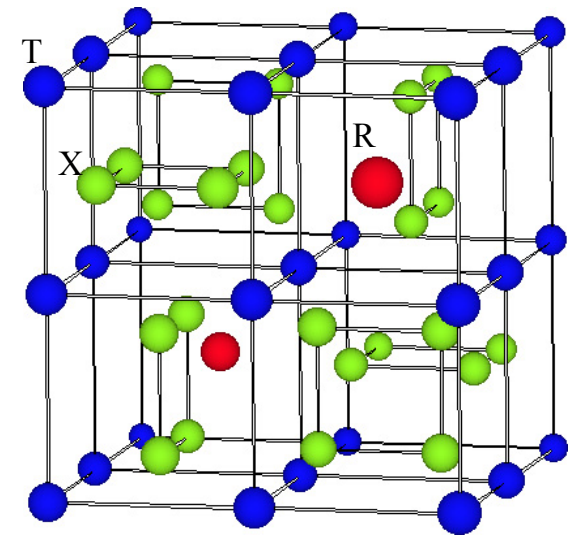

(b)

Fig. 1. Crystal structure of filled skutterudite compound $\left(\mathrm{RT}_{4} \mathrm{X}_{12}\right)$.

晶構造 $\left(\mathrm{LaFe}_{4} \mathrm{P}_{12}\right.$ 型、一般形 $\left.\mathrm{RT}_{4} \mathrm{X}_{12}\right)$ を示す $[1]$ 。結晶 構造は体心立方晶系で、空間群は Im-3 (No. 204) で ある。体心の位置に希土類金属(R)、( $(1 / 4$ 1/4 1/4) の 位置に遷移金属( $\mathrm{T}$ )が入り、6 つの $\mathrm{X}$ 原子が $\mathrm{T}$ 原子 を取り囲み、少し歪んだ正八面体を作っている (Fig.1 (a))。Fig.1 (b)は T 原子の作る単純立方の副格 子が見や寸いように、(1/4 1/4 1/4)だけ移動させた単 位胞である。最隣接 X 原子 4 つが共有結合性の強い 正方形のリングを形成し、この正方形リングが $\mathrm{T}$ 原 子からなる単純立方の副格子 8 つのう 6 つに、方 向を変えて位置し、残る 2 つに $\mathrm{R}$ 原子が位置してい る。この $\mathrm{R}$ 原子が抜けた結晶構造が非充填スクッテ ダイト型構造 $\left(\mathrm{CoAs}_{3}\right.$ 型、一般形 $\left.\mathrm{TX}_{3}\right)$ である。また、 希土類原子 $\mathrm{R}$ に注目寸ると、12 個のプニクトゲン 原子 $\mathrm{X}$ からなる 3 次元ネットワークの大きな空隙

(“かご”) の中に充填されている。この“かご” の中に充填された希土類原子 $\mathrm{R} の 4 \mathrm{f}$ 電子軌道とネ ットワークのプニクトゲン原子 $\mathrm{X}$ の $\mathrm{p}$ 電子の混成効 果の強さの変化がこの物質系の示す多彩な異

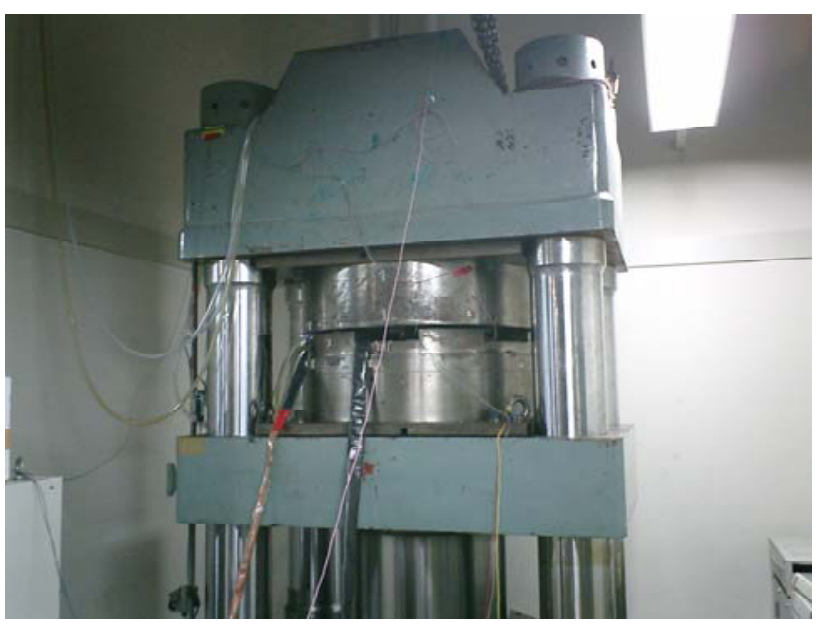

Fig. 2. A wedge-type cubic-anvil high pressure device.

常物性の原因であると考えられている。さらに“か ご”の骨格が大きい $\mathrm{X}=\mathrm{Sb}$ の系では、内包された $\mathrm{R}$ 原子が “かご”の中でランダムな振動（“ラットリ ング”）を起こし、格子熱伝導率を著しく小さくし ていると考えられている[2]。この小さな熱伝導率は 熱電変換材料への応用には必須な性質である。

\section{3. 高圧合成}

従来、スクッテルダイト化合物の合成にはリン化 物ではスズフラックス法、アンチモン化物ではアン チモン自己フラックス法が用いられてきた。しかし、 合成には一ヶ月近くの長時間を要し、しかも、1 mm 以下の小さな試料しか得られないという久点がある。 高圧合成法の利点は短時間で大きな焼結体が得られ ることである。さらに、常圧では合成不可能な物質 も高圧相をクエンチさせることによって合成できる 可能性がある。実際、我々はこれまでに合成の報告 がない多くの充填スクッテルダイト構造を持つ新物 質を合成している。

高圧合成実験には東京大学物性研究所に設置され ている斜面駆動式キュービックアンビル型高圧発生 装置（ 700 ton プレス）を用いた(Fig.2)。キュービ ックアンビル装置には上下ステージに各 3 個のタン グステンカーバイド製アンビルが取り付けられてい る。上側ステージは固定されており、下側ステージ が油圧により上昇し、試料の入ったキューブを加圧 する。その際、アンビルは浅い $\mathrm{V}$ 字形の溝をスライ ドし、6 方向すべてのアンビル面からほぼ等しい力 を加えることができる。アンビルトップの先端面積 は $16 \times 16 \mathrm{~mm}^{2}$ であり、約 $60 \mathrm{~mm}^{3}$ の試料を 6.5 


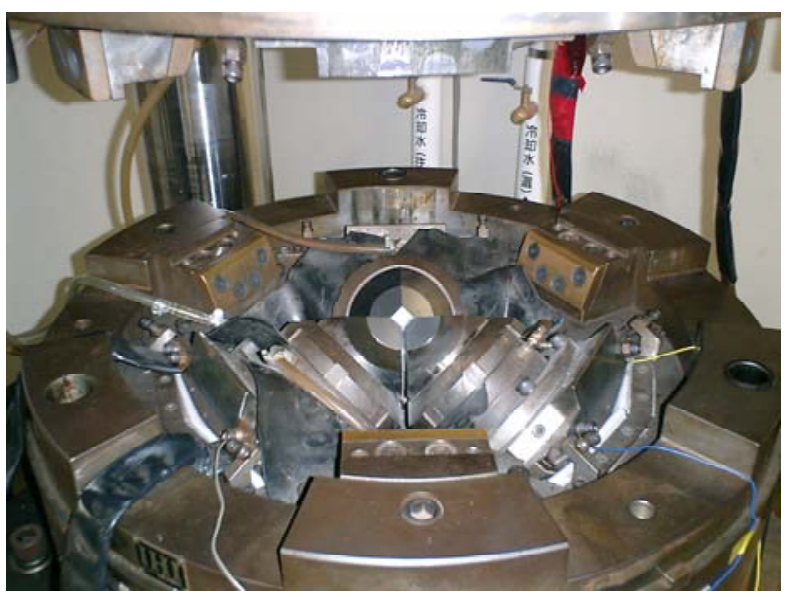

Fig. 3. Lower stage and three anvils.

GPa までの圧力で高温高圧処理できる。Fig.3 に下側 ステージに取り付けられた 3 個のアンビルの写真を 示寸。圧力較正にはビスマス（I-II 転移、2.55 GPa）、 タリウム（II-III 転移 $3.67 \mathrm{GPa}$ )を圧力定点として用 いた。Fig.4 に高圧合成用パーツの構成図を示す。圧 力媒体には一辺 $21 \mathrm{~mm}$ のパイロフィライトキュー ブを用いた。パイロフィライトは含有する水分を飛

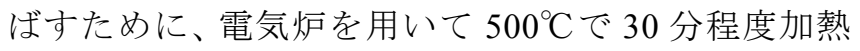
処理したものを使用している。高温発生には円筒形 のグラファイトに電流を流して発熱させる電流加熱 法を用いている。グラファイトヒーターには $2 つ 0$ アンビル面から鉄製のリングとモリブデンのディス クを通して電流を流す。これらのアンビルは加熱を 防ぐため水冷されている。試料部分の温度測定には $\mathrm{R}$ 熱電対を用い、別の 2 つのアンビルを電極として いる。グラファイトヒーターの内側に BN の試料カ プセルが入る。

充填スクッテルダイト化合物の合成には各元素の 粉末を出発物質として用い、圧力 $4 \mathrm{GPa}$ 、温度 850 $\sim 1100^{\circ} \mathrm{C}$ 、保持時間 $30 \sim 120$ 分の後急冷した。試料 は直径 $3 \mathrm{~mm}$ 長さ $8 \mathrm{~mm}$ 程度の円柱状の焼結体とし て得られる。回収した試料は EPMA 及び粉末 X 線 回折実験を行い同定している。合成例として Fig.5 に新物質 $\mathrm{GdRu}_{4} \mathrm{P}_{12}$ の粉末 $\mathrm{X}$ 線回折パターンを示す [3]。観測されたすべてのピークにスクッテルダイト 構造の指数を付けることができ、不純物相は観測さ れていない。この化合物はスズフラックス法等で合 成された報告はなく、高圧下でのみ合成可能な物質 と考えられる。

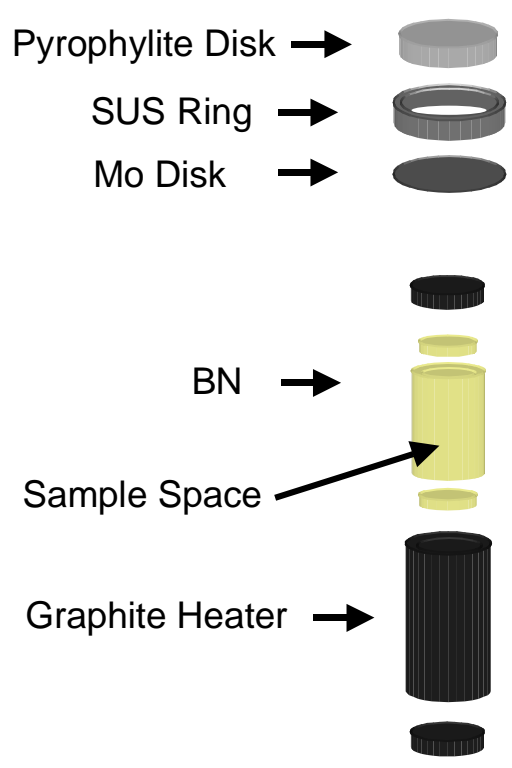

Pyrophylite Cube

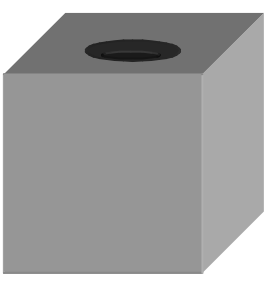

Fig. 4. Schematic illustration of the sample assembly for high-pressure synthesis.

\section{4. スクッテルダイト化合物の物性}

\section{1 熱電特性}

最近、スクッテルダイト構造を持つ化合物が新し い熱電材料として注目されている。二元系のアンチ モン化合物 $\mathrm{CoSb}_{3}, \mathrm{RhSb}_{3}, \mathrm{IrSb}_{3}$ は特有のバンド構造 をもつ $\mathrm{p}$ 型半導体であり、熱電応用にとって望まし い電気特性を示寸 [4]。特に正孔移動度が室温で 2000 $\sim 8000 \mathrm{~cm}^{2} / \mathrm{Vs}$ と大きい[5]。しかし、格子の熱伝導 率が高すぎることが問題である。 3 つの化合物の中 では $\mathrm{CoSb}_{3}$ の格子熱伝導率が最も低く室温で約 0.1 $\mathrm{W} / \mathrm{cmK}$ である $[2]$ 。現在、最良の熱電材料として知 られている $\mathrm{Bi}_{2} \mathrm{Te}_{3}$ 系材料に比べると 7〜8 倍高い。 無次元性能指数 ZT はたかだか 0.5 である。従って、 格子熱伝導率をいかに下げるかが重要な課題である。

Slack が主張するように究極の熱電材料は、電気 


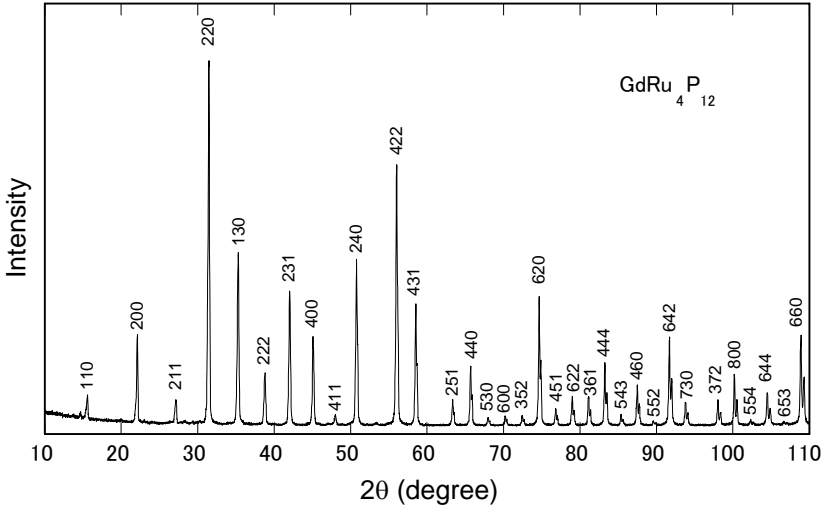

Fig. 5. X-ray diffraction profile of $\mathrm{GdRu}_{4} \mathrm{P}_{12}$ prepared at $1100^{\circ} \mathrm{C}$ and $4 \mathrm{GPa}$.

は結晶のように伝えるが、熱はガラスのようにしか 伝えない材料である $[6]$ 。優れた熱電材料の条件の多 く満足する材料系は $\mathrm{CoSb}_{3}$ の単位格子の中に希土類 元素を充填した、 $\mathrm{LaFe}_{3} \mathrm{CoSb}_{12}, \mathrm{CeFe}_{3} \mathrm{CoSb}_{12}$ などの充 填スクッテルダイト化合物である[2]。これらの化合 物の格子熱伝導率は希土類の “ラットリング効 果” [2]によって $\mathrm{CoSb}_{3}$ の約 1/5 以下に低減できる。 これらの化合物の高温での無次元性能指数 ZT の值 は $800 \mathrm{~K}$ で 1 程度であり、これまで知られているも っとも高い值に匹敵する[2]。

このように熱電材料への応用を目指したスクッテ ルダイト化合物の研究はアンチモン化合物を中心に 精力的に行われている。しかし、充填スクッテルダ イト構造を持つリン化物は試料作成の困難さから、 ほとんど熱電特性が調べられていなかった。我々は 充填スクッテルダイトリン化物 $\mathrm{CeRu}_{4} \mathrm{P}_{12}$, $\mathrm{CeOs}_{4} \mathrm{P}_{12}$ を高圧下で合成し、熱電特性を評価した。 その結果、 $\mathrm{CeRu}_{4} \mathrm{P}_{12}, \mathrm{CeOs}_{4} \mathrm{P}_{12}$ はともに $\mathrm{p}$ 型半導体で あり、 $\mathrm{CeOs}_{4} \mathrm{P}_{12}$ の出力因子は実用レベルの $10^{-3}(\mathrm{~W} /$ $\mathrm{m} \mathrm{K}^{2}$ ) を超えることがわかった[7]。しかし、熱伝導 率が高いため性能指数は小さな值となっている。希 土類サイトの置換等による最適化を行い、熱伝導率 を低下させることが今後の課題である。

\section{2 超伝導}

Meisnerによる $\mathrm{LaFe}_{4} \mathrm{P}_{12}, \mathrm{LaRu}_{4} \mathrm{P}_{12}$ の超伝導の報告 以来[8]、充填スクッテルダイト構造を持つ新超伝導 体の探索が行われ、これまでに、10 種類の超伝導体 が報告されている。Table 1 に各化合物の超伝導転移 温度 $\left(\mathrm{T}_{\mathrm{C}}\right)$ を示す。 $\mathrm{LaRu}_{4} \mathrm{As}_{12}$ はスクッテルダイト化 合物の中で最も高い $\mathrm{T}_{\mathrm{C}}$ を示す[9]。Pr を含む超伝導 体は 3 つ知られているが、特に $\mathrm{PrOs}_{4} \mathrm{Sb}_{12}$ は

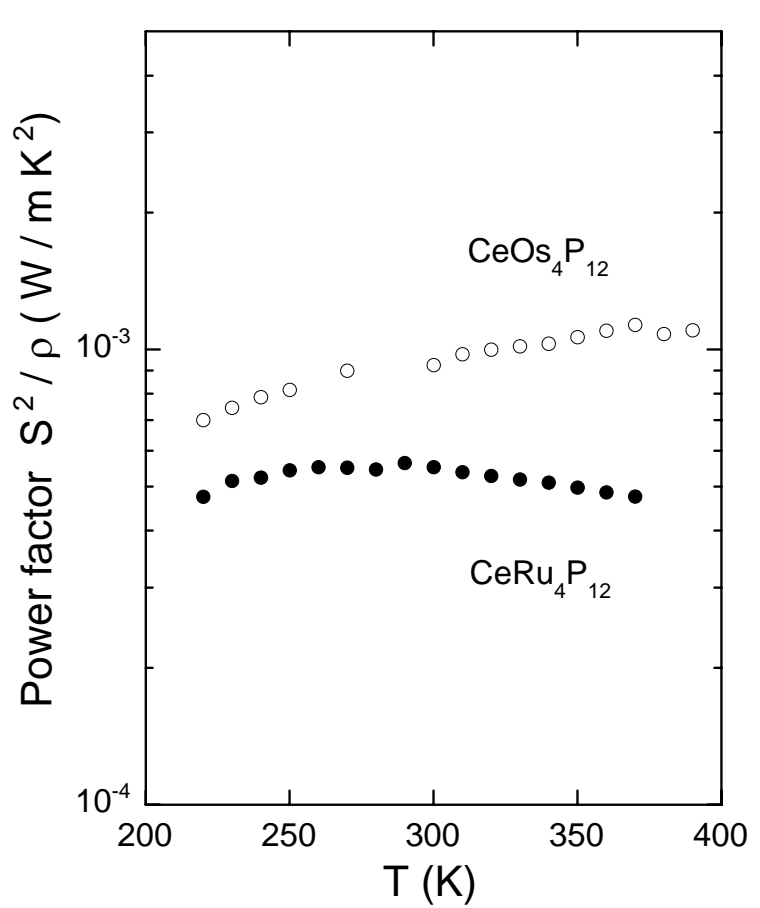

Fig. 6. Power factor $S^{2} / \rho$ as a function of temperature for $\mathrm{CeRu}_{4} \mathrm{P}_{12}$ and $\mathrm{CeOs}_{4} \mathrm{P}_{12}$, where $\mathrm{S}$ is the Seebeck coefficient, $\rho$ is the electrical resistivity.

Pr 化合物で初めての重い電子系超伝導体であり、複 数の超伝導相を有する非 BCS 型の超伝導体である ことが示唆され、その起源に興味が持たれている $[10$, 11]。 $\mathrm{YFe}_{4} \mathrm{P}_{12}$ は我々が初めて高圧下において合成に 成功した新物質である[12]。

Table 1. Filled skutterudite compounds which show superconductivity. $T_{C}$ is superconductivity transition temperature.

\begin{tabular}{|c|c|c|}
\hline Name & $T_{\mathrm{C}}(\mathrm{K})$ & References \\
\hline \hline $\mathrm{LaFe}_{4} \mathrm{P}_{12}$ & 4.1 & {$[8][13][14]$} \\
\hline $\mathrm{LaRu}_{4} \mathrm{P}_{12}$ & 7.2 & {$[8][13][15][16]$} \\
\hline $\mathrm{LaOs}_{4} \mathrm{P}_{12}$ & 1.8 & {$[13][15]$} \\
\hline $\mathrm{LaRu}_{4} \mathrm{As}_{12}$ & 10.3 & {$[9][16][17]$} \\
\hline $\mathrm{LaRu}_{4} \mathrm{Sb}_{12}$ & 3.58 & {$[16][18]$} \\
\hline $\mathrm{LaOs}_{4} \mathrm{Sb}_{12}$ & 0.74 & {$[19]$} \\
\hline $\mathrm{PrRu}_{4} \mathrm{As}_{12}$ & 2.4 & {$[9]$} \\
\hline $\mathrm{PrRu}_{4} \mathrm{Sb}_{12}$ & 1.1 & {$[18]$} \\
\hline $\mathrm{PrOs}_{4} \mathrm{Sb}_{12}$ & 1.85 & {$[10][11][19]$} \\
\hline $\mathrm{YFe}_{4} \mathrm{P}_{12}$ & 5.5 & {$[12]$} \\
\hline
\end{tabular}






Fig. 7. Normalized electrical resistivity $\rho / \rho_{300 \mathrm{~K}}$ vs temperature for $\mathrm{PrRu}_{4} \mathrm{P}_{12}$.

\section{3 金属一絶縁体転移}

充填スクッテルダイト化合物で金属一絶縁体転 移を示すものは $\mathrm{PrRu}_{4} \mathrm{P}_{12}$ と $\mathrm{SmRu}_{4} \mathrm{P}_{12}$ が知られてい る。Fig.7 に $\mathrm{PrRu}_{4} \mathrm{P}_{12}$ の電気抵抗の温度依存性を示 す。室温から温度低下とともに電気抵抗は金属的に 減少するが、60 K 付近で金属一絶縁体転移が観測さ れる $[20]$ 。転移温度 $\left(\mathrm{T}_{\mathrm{MI}}=62 \mathrm{~K}\right)$ で比熱には二次転移 と思われる大きな異常が観測されているが、帯磁率 には顕著な異常は観測されない[21]。また、磁場中

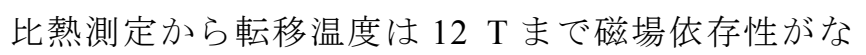
いことが確認されている[21]。これらの実験結果は この金属一絶縁体転移は磁気転移によるものではな いことを示唆している。そこで、金属一絶縁体転移 に伴う構造変化の有無をしらべるため、単結晶試料 を用いた電子線回折、詳細な $\mathrm{X}$ 線回折実験を行っ た。その結果、転移温度以下で超格子反射が観測さ れた[22]。超格子反射は $(\mathrm{h}, \mathrm{k}, \mathrm{l})(\mathrm{h}+\mathrm{k}+\mathrm{l}=$ 奇数 $)$ の場 所に観測され、ユニットセルが体心立方 $(\mathrm{BCC})$ から 単純立方 $(\mathrm{SC})$ になっいると考えられる。低温相の 空間群は超格子反射の強度が小さいため同じ m-3 対称性を持つ、Pm-3 であると予想される。Harima によるバンド計算によると $\mathrm{PrRu}_{4} \mathrm{P}_{12}$ の主要なフェ ルミ面は $\mathrm{P}$ 原子の $\mathrm{p}$ 軌道からなる 1 枚だけであり、 ほとんどサイコロ型をしている[23]。体積はちょう どブリルアンゾーンの半分にあたり $(1,0,0)$ 方向 へのネスティングを起こせばユニットセルは BCC から SCへと変わる。このようなフェルミ面の不安 定さと超格子反射の観測から $\mathrm{PrRu}_{4} \mathrm{P}_{12}$ の金属一絶縁 体転移はフェルミ面のネスティング（例えば，電荷 密度波(CDW)）が起源と考えられる。しかし、ほと

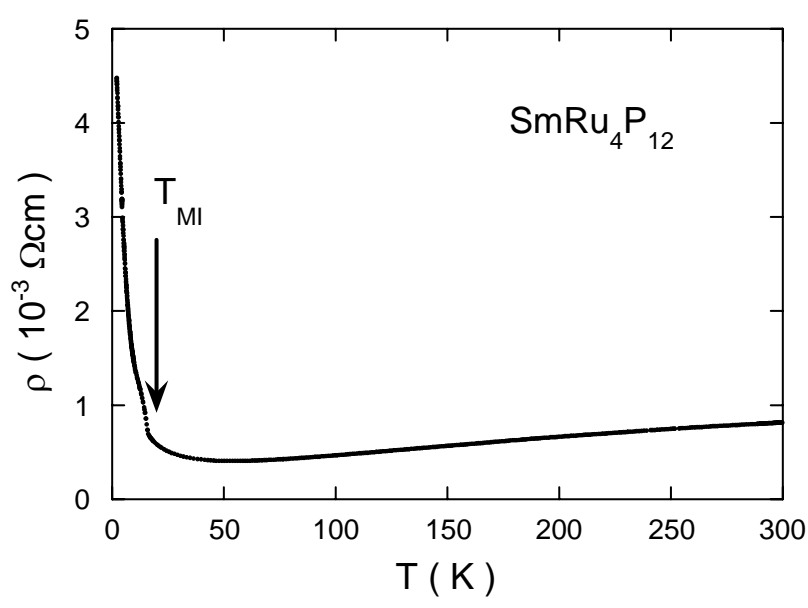

Fig. 8. Electrical resistivity $\rho$ vs temperature for $\mathrm{SmRu}_{4} \mathrm{P}_{12}$.

んど同じバンド構造を持つと考えられる $\mathrm{LaRu}_{4} \mathrm{P}_{12}$ で は金属一絶縁体転移は起らないことから Prの4f電子 が転移に関与している可能性もある。

同様の金属一絶縁体転移は $\mathrm{SmRu}_{4} \mathrm{P}_{12}$ でも観測さ れている(Fig.8)[24]。しかし、 $\mathrm{PrRu}_{4} \mathrm{P}_{12}$ とは対照的 に帯磁率に顕著な異常が見られる。さらに、転移の 詳細な磁場依存性を調べたところ、この金属一絶縁 体転移は連続する二つの転移によって二段階で起 きることがわかった $[25,26]$ 。Fig.9 に磁場中比熱の 結果を示す。零磁場での 1 つのピークは磁場中で二 つのピークにはっきりと分裂している。帯磁率の測 定から Smイオンの価数は 3 価 $\left(4 \mathrm{f}^{5}, \mathrm{~J}=5 / 2\right)$ に近く磁 気エントロピーは転移温度でほぼ、R $\ln 4$ に達する、 このことから結晶場基底状態は 4 重項 $\Gamma_{8}$ と考えら れる。この 4 重項 $\Gamma_{8}$ は磁気的自由度及び軌道

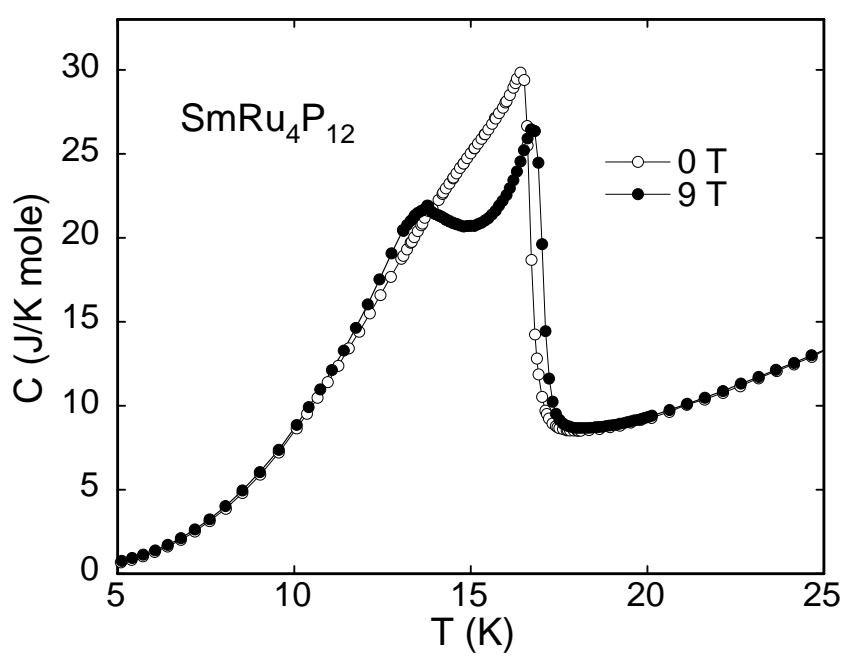

Fig. 9. Specific heat of $\mathrm{SmRu}_{4} \mathrm{P}_{12}$ at zero field and $9 \mathrm{~T}$. 


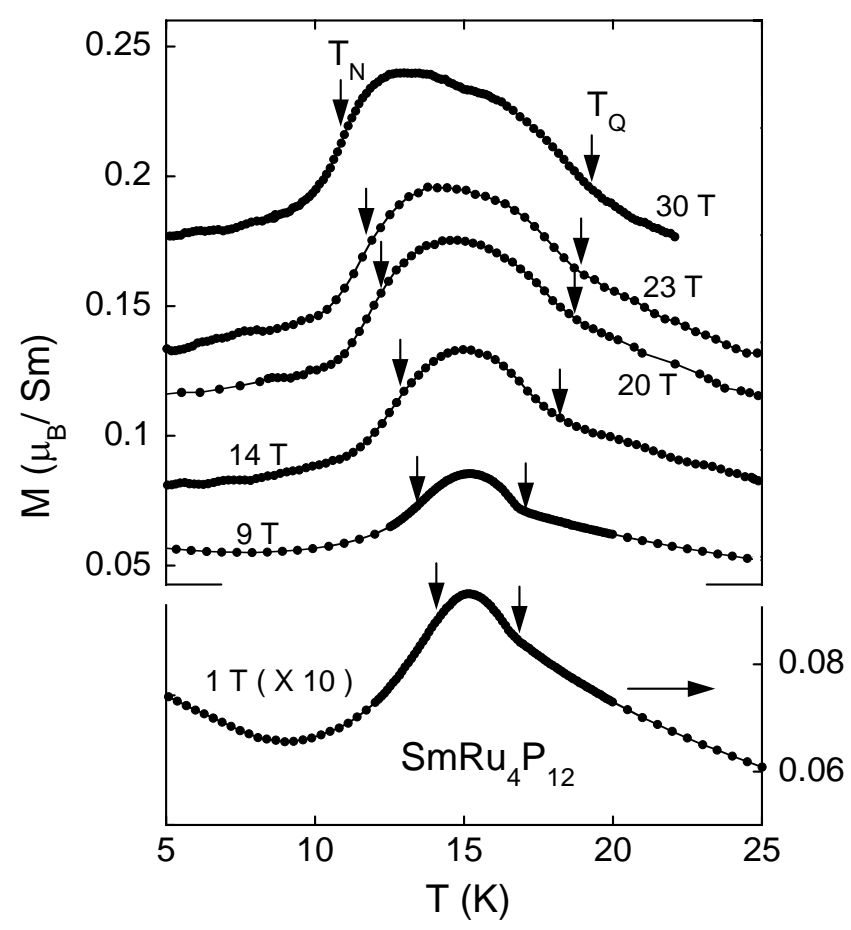

Fig. 10. Temperature dependence of magnetization at various fields.

の自由度を持っているため、この化合物の連続する 2 つの転移は $\mathrm{CeB}_{6}$ で見られるような反強四極子転 移、反強磁性転移である可能性が高い[27]。我々は、 さらに $\mathrm{SmRu}_{4} \mathrm{P}_{12}$ の 2 つの転移を詳しく調べるため $30 \mathrm{~T}$ までの磁場一温度相図を調べた。Fig.10に各磁 場における磁化の温度依存性を示す。磁化の温度微 分が極小、極大を示す温度をそれぞれ、 $\mathrm{T}_{\mathrm{Q}}, \mathrm{T}_{\mathrm{N}}$ とし た。磁化は $\mathrm{T}_{\mathrm{Q}}$ 以下で顕著な上昇を示す。このよう な振舞は反強四極子転移を示寸物質に共通の特徵 である[28]。一方、 $\mathrm{T}_{\mathrm{N}}$ 以下では磁化は減少し、この 転移が反強磁性転移であることを示唆する。Fig.11 に種々の物理量から決定した $\mathrm{T}_{\mathrm{Q}}, \mathrm{T}_{\mathrm{N}}$ の磁場依存性 を示す。 $\mathrm{T}_{\mathrm{Q}}$ は磁場増加とともに高温側にシフトす るが $20 \mathrm{~T}$ 付近からあまり変化しなくなる。このこ とから、より強磁場では $\mathrm{T}_{\mathrm{Q}}$ は低温側にシフトする ことが予想され、 $\mathrm{CeB}_{6}, \mathrm{TmTe}, \mathrm{PrSb}_{3}$ 等で見られる 「リエントラント」な振る舞い[28]を示すと思われ る。Fig.11 で I 相は常磁性金属相、II 相は反強四極 子秩序状態で部分的にギャップが形成された状態、 III 相は完全にギャップが開いた反強磁性絶縁体相 であると考えられる。今後は各相の構造変化の有無、 電気的、磁気的性質などを詳細に調べるため、放射 光を用いた X 線回折実験、中性子散乱実験などを 予定している。

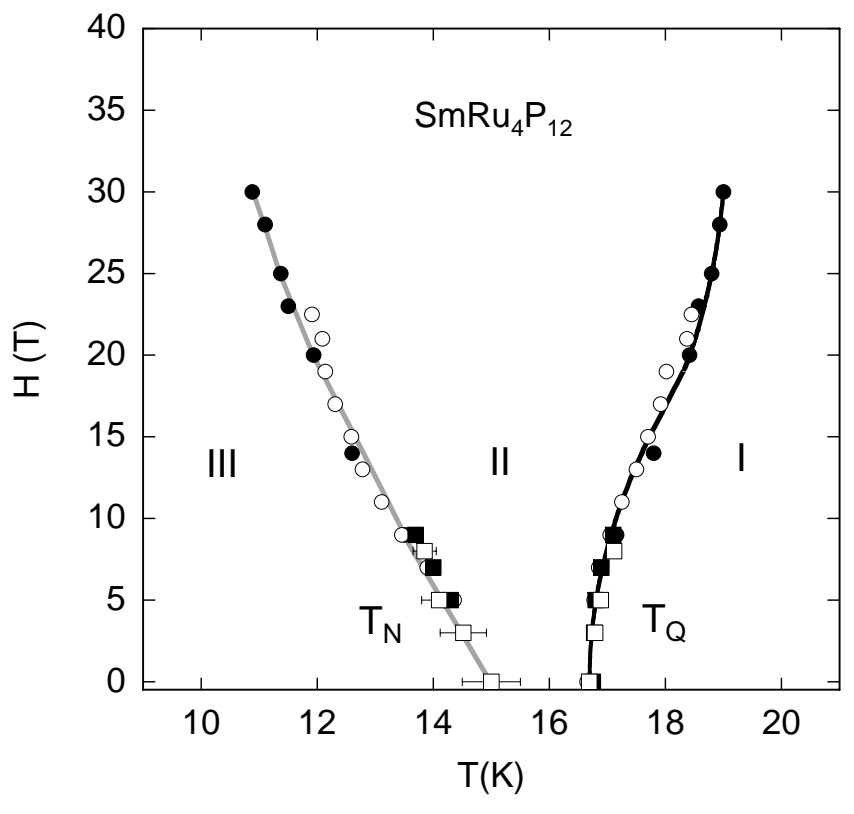

Fig. 11. H-T phase diagram deduced from anomalies of resistivity, magnetization, thermal expansion coefficient and specific heat.

\section{5. おわりに}

スクッテルダイト化合物の高温高圧合成法による 試料作製技術といくつかの化合物の物性を紹介して きた。測定に用いた試料は、放射光を用いた X 線回 折実験、電子線回折実験を除いて高圧下で合成した 多結晶試料である。しかし、中性子散乱、超音波実 験などを行うには大型の単結晶が不可欠となる。そ こで我々は高圧下における大型単結晶育成も試みて いる。試料容積の制限と合成条件を決定するのが困 難であるため、現在のところ $\mathrm{CoP}_{3}$ などいくつかの 化合物に限られてはいるが単結晶の育成に成功して いる[29]。

高圧高温を安定に長時間保持する技術、圧媒体、 試料カプセルに使用する材料の開発など技術的に解 決しなければならない問題も多いが、高圧合成法は 強力な試料作成技術の 1 つである。今後、こうした 手法が一般的になり、試料合成の困難さから研究の 遅れていた化合物や新物質が次々と合成されること を期待する。

\section{謝 辞}

本稿で紹介した研究の一部は、科学研究費: 平成 13年度萌芽研究, ”高圧下におけるスクッテルド鉱 
型化合物の大型単結晶育成と異常な電子物性”, 科 学研究費: 平成 14,15 年度基盤研究(C), “充填スクッ テルダイト型化合物における金属-絶縁体転移の機 構解明” 及び科学研究費: 平成 $14 \sim 16$ 年度基盤研究 (A), “重希土類で置換した新スクッテルド鉱型化合 物の高圧合成と特異な物性” の援助を受けた。ここ に感謝の意を表します。

この研究は多くの方々との共同研究である。東京 大学物性研究所における研究遂行にご協力頂いた八 木健彦先生に深く感謝いたします。産業技術総合研 究所の李哲虎博士には、高圧下の単結晶育成と熱電 特性評価に関してお世話になりました。また、本研 究の遂行には研究室の学生諸君の協力が不可欠であ った。ここに感謝の意を表します。

\section{参考文献}

[1] W. Jeitschko, D. Braun: Acta Crystallogr., Sect. B: Struct. Crystallogr. Chem., 33, 3401 (1977).

[2] B.C. Sales, D. Mandrus, R.K. Williams: Science, 272, 1325 (1996).

[3] C. Sekine, H. Saito, T. Uchiumi, A. Sakai, I. Shirotani: Solid State Commun., 106, 441 (1998).

[4] D.J. Singh, W.E. Pickett: Phys. Rev. B, 50, 11235 (1994).

[5] D.T. Morelli, T. Caillat, J.-P. Fleurial, A. Borshchevsky, J. Vandersande, B. Chen, C. Uher: Phys. Rev. B, 51, 9622 (1995).

[6] G.A. Slack: in CRC Handbook of Thermoelectrics, ed. D.M. Rowe (Chemical Rubber, Boca Raton, Fl., 1995), Chap. 34.

[7] C. Sekine, K. Akita, N. Yanase, I. Shirotani, I. Inagawa, C.H. Lee: Jpn. J. Appl. Phys., 40, 3326 (2001).

[8] G.P. Meisner: Physica, 108B, 763 (1984).

[9] I. Shirotani, T. Uchiumi, K. Ohno, C. Sekine, Y. Nakazawa, K. Kanoda, S. Todo, T. Yagi: Phys. Rev. B, 56, 7866 (1997).

[10] E.D. Bauer, A. Slebarski, E.J. Freeman, N.A. Frederick, B.J. Taylor, C. Sirvent, M.B. Maple: Physica B, 312-313, 230 (2002).

[11] E.D. Bauer, N.A. Frederick, P.-C. Ho, V.S. Zapf, M.B. Maple: Phys. Rev. B, 65, 100506 (2002).

[12] I. Shirotani, Y. Shimaya, K. Kihou, C. Sekine, N. Takeda, M. Ishikawa, T. Yagi: J. Phys.: Condensed Matter, in press.

[13] L.E. DeLong, G.P. Meisner: Solid State Commun., 53, 119 (1985).
[14] M.S. Torikachvili, J.W. Chen, Y. Dalichaouch, R.P. Guertin, M.W. McElfresh, C. Rossel, M.B. Maple, G.P. Meisner: Phys. Rev. B, 36, 8660 (1987).

[15] I. Shirotani, T. Adachi, K. Tachi, S. Todo, K. Nozawa, T. Yagi, M. Kinoshita: J. Phys. Chem. Solids, 57, 211 (1996).

[16] T. Uchiumi, I. Shirotani, C. Sekine, S. Todo, T. Yagi, Y. Nakazawa, K. Kanoda: J. Phys. Chem. Solids, 60, 689 (1999).

[17] I. Shirotani, K. Ohno, C. Sekine, T. Yagi, T. Kawakami, T. Nakanishi, H. Takahashi, J. Tang, A. Matsushita, T. Matsumoto: Physica B, 281\&282, 1021 (2000).

[18] N. Takeda, M. Ishikawa: J. Phys. Soc. Jpn., 69, 868 (2000).

[19] H. Sugawara, S. Osaki, S.R. Saha, Y. Aoki, H. Sato, Y. Inada, H. Shishido, R. Settai, Y. Onuki, H. Harima, K. Oikawa: Phys. Rev. B, 66, 220504 (2002).

[20] C. Sekine, T. Uchiumi, I. Shirotani, T. Yagi: Phys. Rev. Lett., 79, 3218 (1997).

[21] C. Sekine, T. Inaba, I. Shirotani, M. Yokoyama, H. Amitsuka, T. Sakakibara: Physica B, 281\&282, 303 (2000).

[22] C.H. Lee, H. Matsuhata, A. Yamamoto, T. Ohta, H. Takazawa, K. Ueno, C. Sekine, I. Shirotani, T. Hirayama: J. Phys.: Condensed Matter, 13, L45 (2001).

[23] H. Harima, K. Takegahara: Physica B, 312-313, 843 (2002).

[24] C. Sekine, T. Uchiumi, I. Shirotani, T. Yagi: in Science and Technology of High Pressure, Proc. the Int. Conf. on High Pressure Science and Technology (AIRAPT-17), eds. M.H. Manghnani, W.J. Nellis, M.F. Nicol (Universities Press, Hyderabad, India, 2000), pp. 826-829.

[25] K. Matsuhira, Y. Hinatsu, C. Sekine, T. Togashi, H. Maki, I. Shirotani, H. Kitazawa, T. Takamasu, G. Kido, J. Phys. Soc. Jpn., 71, Suppl., 237 (2002).

[26] C. Sekine, I. Shirotani, K. Matsuhira, P. Haen, S. De Brion, G. Chouteau, H. Suzuki, H. Kitazawa, Acta Physica Polonica B, 34, 983 (2003).

[27] J.M. Effantin, J. Rossat-Mignod, P. Burlet, H. Bartholin, S. Kunii, T. Kasuya: J. Magn. Magn. Mater., 47\&48, 145 (1985).

[28] T. Sakakibara, T. Tayama, K. Kitami, M. Yokoyama, K. Tenya, H. Amitsuka, D. Aoki, Y. Onuki, Z. Kletowski, T. Matsumura, T. Suzuki: J. Phys. Soc. Jpn., 69, Suppl. A, 25 (2000).

[29] 特願 2001- 60186 . 